\title{
The ubiquitin-binding protein p62 is expressed in breast cancers showing features of aggressive disease
}

\author{
Phil Rolland, Zahra Madjd, Lindy Durrant, Ian O Ellis ${ }^{1}$, Rob Layfield ${ }^{2}$ and \\ lan Spendlove
}

\author{
Academic and Clinical Department of Oncology, Institute of Infections and Immunity, University of Nottingham, Nottingham City \\ Hospital NHS Trust, Hucknall Road, Nottingham NG5 1PB, UK \\ ${ }^{1}$ Department of Histopathology, University Hospitals Nottingham, Nottingham NG5 1PB, UK \\ ${ }^{2}$ School of Biomedical Sciences, University of Nottingham, Nottingham NG7 2UH, UK \\ (Requests for offprints should be addressed to I Spendlove; Email: ian.spendlove@nottingham.ac.uk)
}

\begin{abstract}
p62 is a multi-functional protein, which induces nuclear factor- $\kappa B(N F \kappa B)$ activation through multiple upstream signalling pathways, including those triggered by the epidermal growth factor (EGF) family of receptors. We hypothesised that p62 overexpression increased EGF family receptor expression and worse outcome in breast cancer would be associated. We stained a tissue microarray representing 523 breast cancers using a commercial guinea pig anti-human p62 sera and standard immunohistochemical methods to address this. Out of $n=106$ tumours, $20.3 \%$ stained positively. p62 expression correlated with grade $(P=0.010)$ and distant metastasis $(P=0.04)$ and EGF receptor (EGFR) $(P=0.012)$, HER2 $(P=0.016)$, HER3 $(P=0.007)$ and HER4 (0.002) expressions. Though expression correlated with reduced 5-year survival (58.5 vs $73.6 \%)$, there was no association with overall disease specific survival. p62 expression may represent a marker of activation of the NFKB pathway.
\end{abstract}

Endocrine-Related Cancer (2007) 14 73-80

\section{Introduction}

p62 (also known as Sequestosome 1) has been characterised as an immediate early response gene, indicating a role in cellular proliferation and differentiation. It encodes a multi-domain protein which has a functional role in the signalling cascades from a range of cell-surface receptors acting as a scaffolding protein in their linkage to nuclear factor- $\kappa \mathrm{B}(\mathrm{NF} \kappa \mathrm{B})$ activation; via IкB ubiquitination (Lee et al. 1998, Karin 1999, Sanz et al. 1999, Geetha \& Wooten 2002, Seibenhener et al. 2004, Wooten et al. 2005). It has an important function in promoting survival signals, including proliferation, differentiation and induction of anti-apoptotic genes (Ciani et al. 2003, Seibenhener et al. 2004). Alterations in the nature of p62 have been shown to occur in benign disease states, such as Paget's disease of bone and conditions characterised by intracellular inclusions including Parkinson's, Alzheimer's and Wilson's diseases (Kuusisto et al. 2002, 2003, Stumptner et al. 2002, Muller et al. 2004, Cavey et al. 2005). Abnormal expression has been documented in various neoplasms including gastrointestinal, prostate and breast cancers (Stumptner et al. 1999, Thompson et al. 2003, Qian et al. 2005, Kitamura et al. 2006).

Breast cancer progression is strongly associated with the expression of the EGF family of receptors (EGFR, HER2, HER3 and HER4), which have been targeted therapeutically (Atalay et al. 2003). These receptors display a range of homo- and heterodimerisation in the presence of multiple ligands and one of the most potent oncogenical receptor is the heterodimerisation of HER2 and HER3 (Gullick 1996, Srinivasan et al. 2001). Signalling from multiple members of the EGFR family has been shown to result in the activation of $\mathrm{NF} \kappa \mathrm{B}$ and this has been implicated in the constitutive activation of NFKB seen in a range of cancers including breast (Bhat-Nakshatri et al. 2002, Le Page et al. 2005, Zhang et al. 2006). p62 expression may be implicated in the regulation of this pathway. 
We hypothesised that p62 overexpression would be associated with breast tumours exhibiting the clinicopathological features of aggressive disease, overexpression of the EGF receptor family members and poorer prognoses. We stained a tissue microarray (TMA) representing 523 breast cancer cases (all having pre-existing EGF receptor family expressions data available from previously published work; Abd El-Rehim et al. 2004b) immunohistochemically in order to investigate this.

\section{Materials and methods}

This research was approved by the Nottingham Local Research Ethics Committee and its design and reporting seeks to adhere to the REMARK recommendations (McShane et al. 2005).

\section{Patients}

A TMA representing 523 cases of primary operable invasive breast carcinoma, from patients aged 70 years or less, diagnosed between 1987 and 1998 from the Nottingham Tenovus Primary Breast Carcinoma Series was used. These well-characterised breast cancer cases have been treated by a conventional algorithm and this series has been successfully used to study the proteomics of breast cancer, being powerful enough to detect small variations in clinical outcome (Madjd et al. 2003, 2004, Abd El-Rehim et al. 2004a, 2005, Putti et al. 2005).

Patient characteristics including age and menopausal status along with information concerning recurrence and survival were maintained on a prospective database. Patients were followed up at 3-month intervals initially, then 6-months and annually for a median period of 76 months.

\section{Tumours}

The characteristics of these cancers including histological grade (grade $1=$ low; grade $2+3=$ high), lymph node stage, tumour size and Nottingham prognostic index (NPI) were prospectively recorded in the database. The tumours were classified into the following four prognostic types for analysis.

1. Excellent prognosis type $(>80 \%, 10$-year survival), including tubulo-lobular, tubular mucinous and invasive cribiform carcinoma.

2. Good types (60-80\%, 10-year survival), including tubular mixed, mixed ductal with special type and alveolar lobular carcinoma.
3. Moderate prognosis type (50-60\%, 10-year survival), including classical lobular, medullary, atypical medullary and lobular mixed carcinoma.

4. Poor prognosis types ( $\leq 50 \%$ 10-year survival), including ductal NST, solid lobular, mixed ductal and lobular carcinoma.

\section{Treatment}

Patient management was guided by NPI and oestrogen receptor (ER) status. The assays to determine the ER status of each tumour section were conducted by a dextran-coated charcoal technique at the Tenovus Institute, Cardiff. A cut-off of $10 \mathrm{fmol} / \mathrm{mg}$ protein indicated positivity. Those women with an NPI score $\leq 3.4$ received no adjuvant therapy and those with an NPI score $>3.4$ received tamoxifen if ER-positive $( \pm$ Zoledex if pre-menopausal) or CMF (cyclophosphamide, methotrexate, flurouracil) if ER-negative and fit enough to receive it.

\section{TMA preparation}

The excised tumours were sliced, fixed immediately, placed in neutral buffered formalin and processed through to embedding in paraffin wax. Tumour samples were then arrayed as described previously (Kononen et al. 1998). Tumour biopsies with a diameter of $0.6 \mathrm{~mm}$ were taken from representative regions of each donor block using manual tissue arrayer (Beecher Instruments, WI, USA) and then precisely arrayed into a new recipient paraffin block. Contrary to expectation, tissue heterogeneity does not significantly influence the predictive power of the TMA results. Single cores were analysed in this study (Bubendorf et al. 2001, Torhorst et al. 2001).

\section{Immunohistochemistry}

- Primary antibody

p62: A commercial polyclonal guinea pig antihuman p62 (C-terminal specific) antibody was used as the primary antibody (Research Diagnostics, INC New Jersey, USA). Its optimal dilution following titration on whole breast sections was found to be $1 / 1000$.

\section{- Peptide-blocking assay}

To demonstrate the specificity of the antisera on immunohistochemical staining, BSA-conjugated peptide NYDIGAALDTIQYSKHPPPL (M1044-A8 Alta Bioscience) - the peptide to which it had been 
raised - was pre-incubated with the anti-p62 antisera for $1 \mathrm{~h}$ at $4{ }^{\circ} \mathrm{C}$ prior to its addition to the sections. Titrations of peptide from 0.25 to $20 \mu \mathrm{g} / \mathrm{ml}$ were carried out at a constant, optimal concentration of antisera (1:1000 dilution).

\section{- Staining protocol}

Deparaffinised $4 \mu \mathrm{m}$ thick sections of TMA and similar thickness whole sections of breast tumours $(X$ 10) were immersed in $0.3 \%$ hydrogen peroxide for $15 \mathrm{~min}$ to block endogenous peroxidase activity. Microwave pretreatment in EDTA buffer ( $\mathrm{pH}$ 8.5) was performed at $10 \mathrm{~min}$ high power and $10 \mathrm{~min}$ low power to retrieve antigenicity. The primary antibody was incubated on the slides for $60 \mathrm{~min}$ at a dilution of 1:1000. Primary antibody was omitted from the negative control, which was left incubating in normal swine serum (NSS). Sections of breast tumour found to express p62 acted as positive and negative controls. The sections were then incubated with a HRP-conjugated rabbit anti-guinea pig secondary antibody (Dakocytomation, Cambridgeshire, UK) for $45 \mathrm{~min}$. 3,3'-Diaminobenzidne (Dako) was applied for visualisation. The sections were lightly counterstained with haematoxylin (Dako), dehydrated in alcohol, cleared with xylene (Genta Medica, York, UK) and mounted with distyrene, plasticiser and xylene (DPX; BDH, Poole, England).

- Evaluation of staining

On reviewing the distribution, variety and frequency of staining within cores we adopted a binary system of quantifying the expression of p62. Those cores with $>5 \%$ of cells staining with intensity $\geq 1$ were deemed positive and others negative. The complete scoring was performed by one author ( $\mathrm{P} \mathrm{R})$, a high level of concordance with a second author $(\mathrm{Z} \mathrm{M})$ having being achieved over an initial 100 cases.

\section{- EGFR, HER2, HER3 and HER4}

Immunohistochemical staining of these markers was performed as described previously using the standard streptavidin biotin complex (Abd El-Rehim et al. 2004b).

\section{Statistical analysis}

SPSS vs 12.0 was used for the statistical analyses (Chicago, IL, USA). Univariate associations of p62 staining with the clinicopathological parameters of breast cancer, the expression of the EGF family of receptors and 5 -year survival were analysed by Pearson's $\chi^{2}$-test.
The effect of p62 expression upon overall diseasespecific survival was analysed using Kaplan-Meier curves and the log rank test. To estimate the size and independence of effects, Cox's regression was employed; returning hazards ratios and $95 \%$ confidence intervals.

$P$ values $<0.05$ indicated statistically significant differences.

\section{Results}

\section{Clinicopathological characteristics}

At the time of diagnosis, the patient age in this series of cases ranged from 27 to 70 years (mean $=53.5$ years) and $61.2 \%(n=301)$ were post-menopausal. Out of $n=168$, $32.7 \%$ had tumours less than $1.5 \mathrm{~cm}$ in size, $63.8 \%(n=$ $329)$ were stage $1,17.7 \%(n=92)$ were low grade and $15.3 \%(n=80)$ had distant metastases. Out of $n=312$, $60.9 \%$ had a poor tumour type and most tumours, $54.1 \%$ $(n=272)$, were in the moderate NPI group $(>3.4 \leq 5.4)$. Out of $n=334,67.1 \%$ were ER-positive. Recurrence of disease occurred in $24.7 \%(n=129)$ of cases and the 5 -year survival was $70.6 \%(n=369)$ (Table 1$)$.

Table 1 The major clinicopathological characteristics of the whole series and association of positive p62 expression with clinicopathological parameters in a univariate analysis using the Pearson's $\chi^{2}$-test

\begin{tabular}{|c|c|c|c|}
\hline & \multicolumn{2}{|c|}{ No. of cases (\%) } & \multirow[b]{2}{*}{$\chi^{2}(P=)( \pm)$} \\
\hline & $\begin{array}{c}\text { p62- } \\
\text { positive } \\
(n=106)\end{array}$ & $\begin{array}{c}\text { p62- } \\
\text { negative } \\
(n=417)\end{array}$ & \\
\hline Tumour size & $n=106$ & $n=408$ & \\
\hline$<1.5 \mathrm{~cm}$ & $31(29.2)$ & $137(33.6)$ & \\
\hline$\geq 1.5 \mathrm{~cm}$ & $75(70.8)$ & 271 (66.4) & $0.718(0.397)$ \\
\hline Stage & $n=105$ & $n=411$ & \\
\hline LN-negative & $69(65.7)$ & 260 (63.3) & \\
\hline LN-positive & $36(34.4)$ & $151(36.7)$ & $0.218(0.641)$ \\
\hline Distant mets & $n=106$ & $n=417$ & \\
\hline Absent & $83(78.3)$ & $360(86.3)$ & \\
\hline Present & $23(21.7)$ & 57 (13.7) & $4.205(0.040)(+)$ \\
\hline Grade & $n=106$ & $n=413$ & \\
\hline Low & $10(9.4)$ & $82(19.9)$ & \\
\hline High & $96(90.6)$ & $331(80.1)$ & $6.281(0.012)(+)$ \\
\hline Tumour type & $n=104$ & $n=408$ & \\
\hline 1 & $4(3.8)$ & $28(6.9)$ & \\
\hline 2 & $15(14.4)$ & $90(22.1)$ & \\
\hline 3 & $11(10.6)$ & $52(12.7)$ & \\
\hline 4 & $74(71.2)$ & 238 (58.3) & $6.115(0.106)$ \\
\hline Five year DSS & $n=106$ & $n=417$ & \\
\hline $\begin{array}{l}\text { Survived to } \\
5 \text { years }\end{array}$ & $62(58.5)$ & $307(73.6)$ & \\
\hline $\begin{array}{l}\text { Died within } \\
5 \text { years }\end{array}$ & $44(41.5)$ & $110(26.4)$ & $9.313(0.002)(+)$ \\
\hline
\end{tabular}

LN, lymph node status; Mets, metastases; DSS, disease-specific survival; NPI, Nottingham prognostic index; \pm , positive/inverse associations. 


\section{p62 staining}

Tissue staining with the p62 antisera decreased as peptide concentration increased, supporting the specificity of this antibody in staining for the protein it was raised against (Fig. $1 \mathrm{~b}$ and c). The staining of the TMA cores reflected that observed in whole sections. The staining observed was granular, cytoplasmic and homogenous; nuclear staining was rarely observed and cell membrane staining did not occur (Fig. 2a). Out of $n=106,20.3 \%$ of cases stained positive for p62 and $79.7 \%(n=417)$ were p62-negative (Fig. 2b).

\section{Univariate associations of p62 expression with clinicopathological factors, the EGF family of receptors and 5 year survival $\left(\chi^{2}\right)$}

When tumours staining positive for p62 were compared with known histological prognostic factors (stage, tumour size, grade, etc.), patient characteristics (age, menopausal status, etc.) and outcome (recurrence and 5-year survival); p62-positive staining was seen to be associated with higher grade $(9.184 ; P=0.010)$ and the presence of distant metastases (4.205; $P=0.040)$. p62-positive cases were less likely to survive to 5 years (58.5 vs 73.6\%; 9.313; $P=0.002$; Table 1). p62-positive

(a)

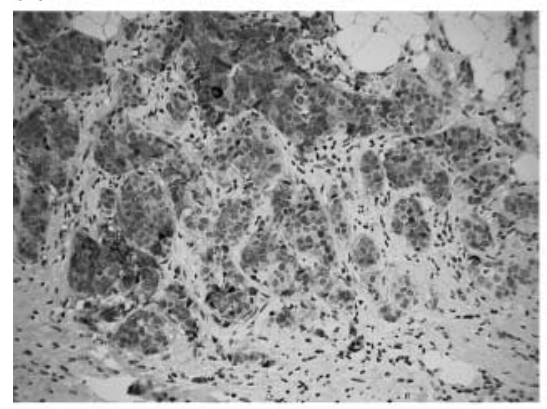

(c)

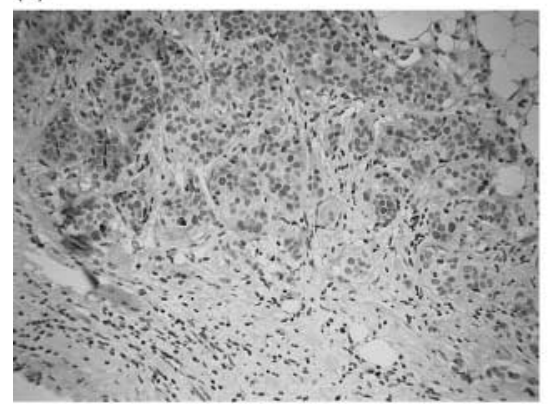

tumours were more likely to express all of the EGF family of receptors than their negative counterparts (EGFR: $P=0.012$; HER2: $P=0.016$; HER3: $P=0.007$; HER4: $P=0.002$; Table 2).

\section{Association of p62 expression with overall disease-specific survival}

p62 expression did not predict the overall diseasespecific survival (log rank $0.93 ; P=0.34)$ in univariate or multivariate analyses (Fig. 3; Table 3).

\section{Discussion}

In this breast cancer array of 523 tumours, a clear staining pattern of p62 expression was seen in $20 \%$ of cases. As there is a paucity of data concerning the immunohistochemical expression of p62 in normal and cancerous breast tissue, it is not possible to draw conclusions about whether this represents overexpression in some cancers or underexpression in others. Despite this, as earlier work by western blot on the 13 lysates out of 9 normal and 4 cancerous breast tissues concluded that the p62 protein was relatively overexpressed in tumours (Thompson et al. 2003), one might speculate that those tumours

(b)

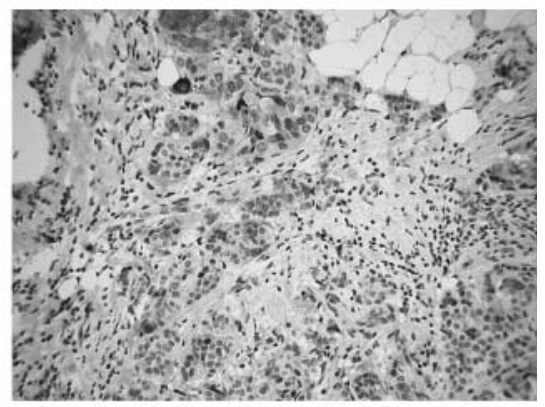

(d)

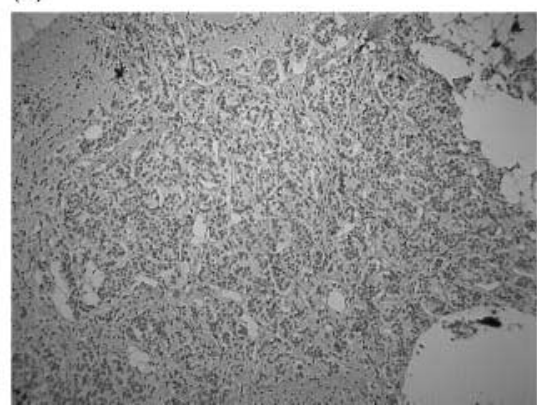

Figure 1 (a) Whole section of breast cancer known to stain positive with 1/1000 dilution of p62 antisera co-incubated with no blocking peptide; positive control. (b) Whole section of breast cancer known to stain positive with 1/1000 dilution of p62 antisera co-incubated with blocking peptide at $1 / 1000$ dilution showing reduced staining. (c) Whole section of breast cancer known to stain positive with $1 / 1000$ dilution of p62 antisera co-incubated with blocking peptide at 1/50 dilution showing almost absent staining. (d) Whole section of breast cancer known to stain positive with $1 / 1000$ dilution of $p 62$ antisera with normal swine serum substituted for the p62 antisera; negative control. 

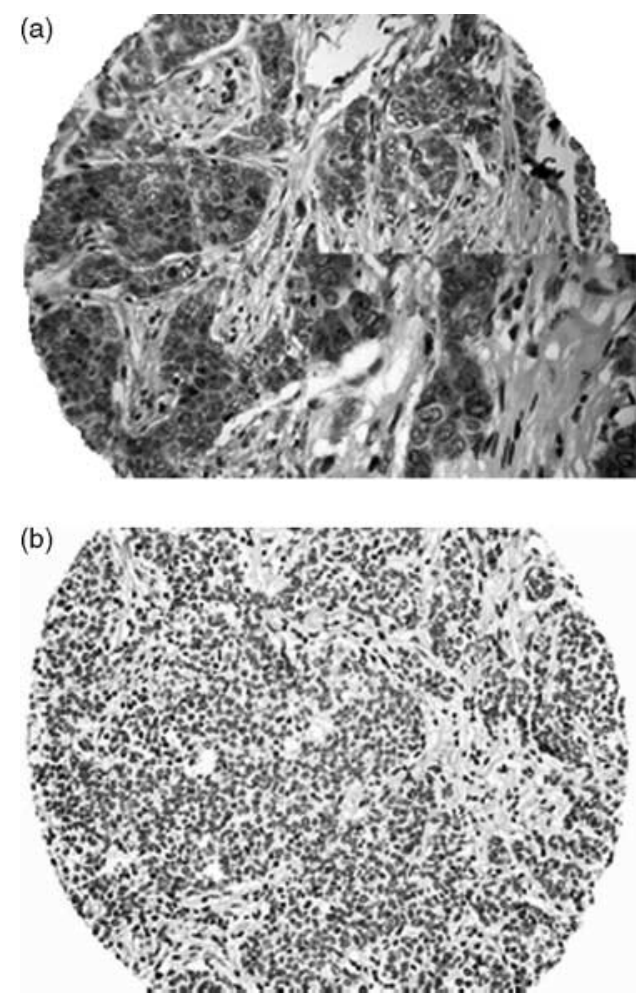

Figure 2 (a) An example of a high-grade breast cancer core illustrating the cytoplasmic staining observed with p62 antisera at $1 / 1000$ dilution at $\times 200$ and $\times 400$ magnification. Stroma, cell membrane and nucleus consistently exhibited no staining. (b) An example of a breast cancer core not reacting to the p62 antisera at $1 / 1000$ and therefore classified as p62 negative at $\times 200$ magnification.

deviating most from normality would be the ones to express most p62 protein as evidenced by a positive reaction to the immunohistochemical staining. The univariate associations with advancing grade and the presence of metastases we observed in positively staining

Table 2 Association of positive p62 expression with the epidermal growth factor (EGF) family of receptors using the Pearson $\chi^{2}$ test

\begin{tabular}{lccc}
\hline Biomarker & $\begin{array}{c}\text { p62-positive } \\
(n=106)\end{array}$ & $\begin{array}{c}\text { p62-negative } \\
(n=417)\end{array}$ & $\chi^{2}(P=)$ \\
\hline EGFR- & $n=99 ;$ & $n=354 ;$ & $6.35(0.012)$ \\
positive & $28(28.3)$ & $60(16.9)$ & \\
HER2-positive & $n=106 ;$ & $n=401 ;$ & $5.85(0.016)$ \\
& $50(47.2)$ & $138(34.4)$ & \\
HER3-positive & $n=93 ;$ & $n=344 ;$ & $7.152(0.007)$ \\
& $86(92.5)$ & $278(80.8)$ & \\
HER4-positive & $n=96 ;$ & $n=344 ;$ & $9.924(0.002)$ \\
& $84(87.5)$ & $247(71.8)$ & \\
\hline
\end{tabular}

EGFR, epidermal growth factor receptor (clone 113, NCL-LEGFR, Novocastra, Newcastle, UK); HER2, (Dako, Denmark); HER3, (Clone RTJ1, NCL-c-erbB-3, Novocastra, Newcastle, UK); HER4, (clone HFR1, RB-9045-R7, Neomarkers, CA, USA).

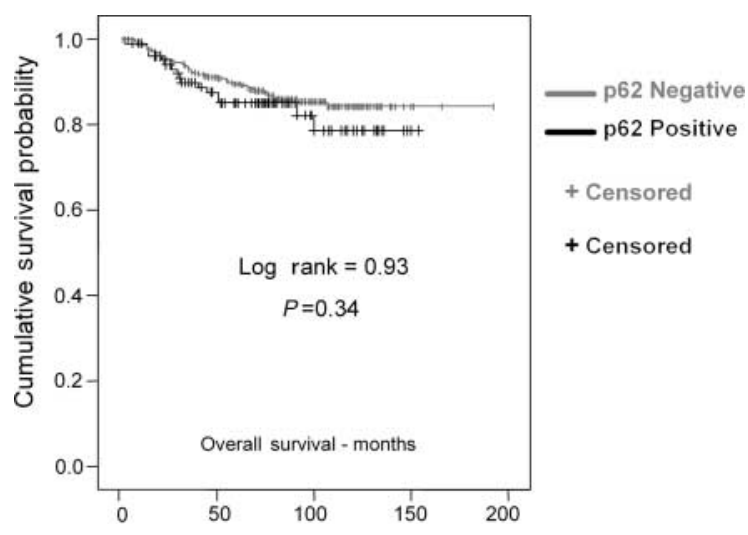

Figure 3 A Kaplan-Meier plot illustrating how disease-specific survival varies with p62 expression; the log rank test confirming no statistically significant differences.

tumours would support this thinking. Though we failed to find a concordant association with the overall survival, p62 expression did correlate with short-term (5-year) survival. This might be explained by its association with those tumours having distant metastases at presentation; a small but important group with a mean survival 45 when compared with 168 months for the series overall. p62 expression was shown not to be an independent prognostic factor and indeed its association with higher grade and indirectly stage (of which distant metastases is a subset) made it unlikely that it could be. Our observation that $20 \%$ of breast cancers positively express p62 was lower than the proportion seen in smaller series of prostate (91\%) and digestive system cancers (100\%), and possibly reflects site-specific variations in tumour biology, though methodological differences remain an alternative explanation. The distribution of staining observed and the associations we found with grade and

Table 3 Cox's regressional multivariate analysis of p62 expression versus known independent prognostic factors in breast cancer

\begin{tabular}{lll}
\hline & $\begin{array}{c}\text { Hazard ratio (95\% } \\
\text { confidence intervals) }\end{array}$ & Significance $(P=)$ \\
\hline Stage & & \\
LN-negative & & 0.01 \\
LN-positive & $2.35(1.44-3.83)$ & 0.01 \\
Tumour size $>$ & $4.93(1.97-12.34)$ & \\
$1.5 \mathrm{~cm}$ & & \\
Grade & & 0.036 \\
Low & & 0.366 \\
High & $4.58(1.11-18.97)$ & \\
Positive p62 & $1.30(0.74-2.29)$ & \\
expression & & \\
\hline
\end{tabular}

$\mathrm{LN}$, lymph node status. 
metastatic disease were, however, the same for the three sites (Su et al. 2005, Kitamura et al. 2006).

A variety of signals from upstream receptors and pathways may be transduced to NFKB activation by $\mathrm{p} 62$ connecting to atypical protein kinase $\mathrm{C}$ and activating inhibitor of $\mathrm{NFKB}$ kinase $\mathrm{B}$ subunit (IKK $\beta$ ) by phosphorylation in its scaffolding role (Karin 1999, Sanz et al. 1999, Wooten et al. 2005). The freed NFкB is subsequently translocated into the nucleus where it can promote cellular de-differentiation, proliferation, invasion, metastasis and reduced apoptosis (Barkett \& Gilmore 1999, Chiarugi et al. 1999, Dong et al. 2002, Andela 2004). Recent studies demonstrating that the EGF family is able to activate the NFKB-signalling pathway offer an explanation for the constitutive NFKBpathway activation seen in a range of tumours including breast cancer (Bhat-Nakshatri et al. 2002, Le Page et al. 2005, Zhang et al. 2006) and as there is a strong positive correlation between the expression of p62, HER3 and HER4 in this work, p62 expression may provide further mechanistic insight. Although HER3 is functionally unable to transduce a signal to the cytoplasmic side of the plasma membrane, as its kinase domain is inactive, it is one of the most potent oncogenic members of the EGF family. This is due to its ability to form heterodimers with HER2. This heterodimerisation process is common to all members of the EGF family, allowing a wide range of signalling possibilities and signal strengths depending on precise dimerisation and the ligands used (Wallasch et al. 1995, Gullick 1996, Roskoski 2004).

An associated function of p62 is its binding to polyubiquitinated proteins and its subsequent shuttling of them to the proteosome for degradation. This mechanism may be important in tumour biology and also in Paget's disease (Ciani et al. 2003, Goodsell 2003, Seibenhener et al. 2004). p62 is an important scaffold in the RANK-signalling pathway in osteoclasts and in Pagets's disease mutations in the ubiquitin-associated domain that results in loss of function are believed to promote osteoclastogenesis via activation of $\mathrm{NF} \kappa \mathrm{B}$ (Hocking et al. 2004, Cavey et al. 2005). Interestingly, the majority of primary bone cancers occurring in adulthood do so in patients with Paget's disease (Huvos 1986).

Autoantibodies to p62 have been observed more frequently in the sera of patients with gastrointestinal cancers that have metastasised (Su et al. 2005). This suggests that p62 may mutate into an autoantigen as cancer advances and preliminary work in prostate cancer supports this theory (Shi et al. 2005, Su et al. 2005). This is yet to be investigated in breast cancer but the close correlation of p62 with EGFR family, its relationship with $\mathrm{NF} \kappa \mathrm{B}$ and this potential to elicit an immune response make p62 an intriguing potential target for intervention.

In summary, we have demonstrated for the first time that p62 expression in breast cancer is associated with tumour progression, identifying a distinct set of tumours. The expression of p62 correlates with the expression of members of the EGF family, particularly HER3 and HER4 and may represent a marker of activation of the NFKB pathway.

\section{Acknowledgements}

PR performed the experimental work, the analyses and co-wrote the manuscript. Z M produced the TMA and was responsible for the co-analysis of tissue and data. L D co-supervised the experimental work. I E provided the pre-existing database and patient specimens. R L co-authored the manuscript. I S supervised the experimental work, conceived the project and co-wrote the manuscript. Claire Paish and Dalia M Abd El-Rehim are thanked for their work producing the existing database.

\section{Funding}

There was no external source of funding for this project, no conflict of interest that would prejudice its impartiality, and no conflicts of interest, which have not been previously declared.

\section{References}

Abd El-Rehim DM, Pinder SE, Paish CE, Bell J, Blamey RW, Robertson JF, Nicholson RI \& Ellis IO 2004a Expression of luminal and basal cytokeratins in human breast carcinoma. Journal of Pathology 203 661-671.

Abd El-Rehim DM, Pinder SE, Paish CE, Bell JA, Rampaul RS, Blamey RW, Robertson JF, Nicholson RI \& Ellis IO $2004 \mathrm{~b}$ Expression and co-expression of the members of the epidermal growth factor receptor (EGFR) family in invasive breast carcinoma. British Journal of Cancer 91 1532-1542.

Abd El-Rehim DM, Ball G, Pinder SE, Rakha E, Paish C, Robertson JF, Macmillan D, Blamey RW \& Ellis IO 2005 High-throughput protein expression analysis using tissue microarray technology of a large well-characterised series identifies biologically distinct classes of breast cancer confirming recent cDNA expression analyses. International Journal of Cancer 116 340-350. 
Andela VB 2004 Functional antagonism between NF-kappaB and nuclear receptors: implications in carcinogenesis and strategies for optimal cancer chemopreventive interventions. Current Cancer Drug Targets 4 337-344.

Atalay G, Cardoso F, Awada A \& Piccart MJ 2003 Novel therapeutic strategies targeting the epidermal growth factor receptor (EGFR) family and its downstream effectors in breast cancer. Annals of Oncology 14 1346-1363.

Barkett M \& Gilmore TD 1999 Control of apoptosis by Rel/NFkappaB transcription factors. Oncogene 18 6910-6924.

Bhat-Nakshatri P, Sweeney CJ \& Nakshatri H 2002 Identification of signal transduction pathways involved in constitutive NF-kappaB activation in breast cancer cells. Oncogene 21 2066-2078.

Bubendorf L, Nocito A, Moch H \& Sauter G 2001 Tissue microarray (TMA) technology: miniaturized pathology archives for high-throughput in situ studies. Journal of Pathology 195 72-79.

Cavey JR, Ralston SH, Hocking LJ, Sheppard PW, Ciani B, Searle MS \& Layfield R 2005 Loss of ubiquitin-binding associated with Paget's disease of bone p62 (SQSTM1) mutations. Journal of Bone and Mineral Research 20619 624.

Chiarugi V, Magnelli L, Chiarugi A \& Gallo O 1999 Hypoxia induces pivotal tumor angiogenesis control factors including p53, vascular endothelial growth factor and the NFkappaB-dependent inducible nitric oxide synthase and cyclooxygenase-2. Journal of Cancer Research and Clinical Oncology 125 525-528.

Ciani B, Layfield R, Cavey JR, Sheppard PW \& Searle MS 2003 Structure of the ubiquitin-associated domain of p62 (SQSTM1) and implications for mutations that cause Paget's disease of bone. Journal of Biological Chemistry 278 37409-37412.

Dong QG, Sclabas GM, Fujioka S, Schmidt C, Peng B, Wu T, Tsao MS, Evans DB, Abbruzzese JL, McDonnell TJ et al. 2002 The function of multiple IkappaB: NF-kappaB complexes in the resistance of cancer cells to Taxolinduced apoptosis. Oncogene 21 6510-6519.

Geetha T \& Wooten MW 2002 Structure and functional properties of the ubiquitin binding protein p62. FEBS Letters 512 19-24.

Goodsell DS 2003 The molecular perspective: ubiquitin and the proteosome. Oncologist 8 293-294.

Gullick WJ 1996 The c-erbB3/HER3 receptor in human cancer. Cancer Surveys 27 339-349.

Hocking LJ, Lucas GJ, Daroszewska A, Cundy T, Nicholson GC, Donath J, Walsh JP, Finlayson C, Cavey JR, Ciani B et al. 2004 Novel UBA domain mutations of SQSTM1 in Paget's disease of bone: genotype phenotype correlation, functional analysis, and structural consequences. Journal of Bone and Mineral Research 19 1122-1127.

Huvos AG 1986 Osteogenic sarcoma of bones and soft tissues in older persons. A clinicopathologic analysis of 117 patients older than 60 years. Cancer 57 1442-1449.
Karin M 1999 The beginning of the end: IkappaB kinase (IKK) and NF-kappaB activation. Journal of Biological Chemistry 274 27339-27342.

Kitamura H, Torigoe T, Asanuma H, Hisasue SI, Suzuki K, Tsukamoto T, Satoh M \& Sato N 2006 Cytosolic overexpression of p62 sequestosome 1 in neoplastic prostate tissue. Histopathology 48 157-161.

Kononen J, Bubendorf L, Kallioniemi A, Barlund M, Schraml P, Leighton S, Torhorst J, Mihatsch MJ, Sauter G \& Kallioniemi OP 1998 Tissue microarrays for highthroughput molecular profiling of tumor specimens. Nature Medicine 4 844-847.

Kuusisto E, Salminen A \& Alafuzoff I 2002 Early accumulation of p62 in neurofibrillary tangles in Alzheimer's disease: possible role in tangle formation. Neuropathology and Applied Neurobiology 28 228-237.

Kuusisto E, Parkkinen L \& Alafuzoff I 2003 Morphogenesis of Lewy bodies: dissimilar incorporation of alpha-synuclein, ubiquitin, and p62. Journal of Neuropathology and Experimental Neurology 62 1241-1253.

Le Page C, Koumakpayi IH, Lessard L \& Mes-Masson AM 2005 EGFR and Her-2 regulate the constitutive activation of NF-kappaB in PC-3 prostate cancer cells. Prostate $\mathbf{6 5}$ 130-140.

Lee YH, Ko J, Joung I, Kim JH \& Shin J 1998 Immediate early response of the p62 gene encoding a non-proteasomal multiubiquitin chain binding protein. FEBS Letters 438 297-300.

McShane LM, Altman DG, Sauerbrei W, Taube SE, Gion M \& Clark GM 2005 Reporting recommendations for tumour MARKer prognostic studies (REMARK). European Journal of Cancer 41 1690-1696.

Madjd Z, Pinder SE, Paish C, Ellis IO, Carmichael J \& Durrant LG 2003 Loss of CD59 expression in breast tumours correlates with poor survival. Journal of Pathology 200 633-639.

Madjd Z, Durrant LG, Bradley R, Spendlove I, Ellis IO \& Pinder SE 2004 Loss of CD55 is associated with aggressive breast tumors. Clinical Cancer Research 10 2797-2803.

Muller T, Langner C, Fuchsbichler A, Heinz-Erian P, Ellemunter H, Schlenck B, Bavdekar AR, Pradhan AM, Pandit A, Muller-Hocker J et al. 2004 Immunohistochemical analysis of Mallory bodies in Wilsonian and non-Wilsonian hepatic copper toxicosis. Hepatology 39 963-969.

Putti TC, El-Rehim DM, Rakha EA, Paish CE, Lee AH, Pinder SE \& Ellis IO 2005 Estrogen receptor-negative breast carcinomas: a review of morphology and immunophenotypical analysis. Modern Pathology 18 26-35.

Qian HL, Peng XX, Chen SH, Ye HM \& Qiu JH 2005 p62 Expression in primary carcinomas of the digestive system. World Journal of Gastroenterology 11 1788-1792.

Roskoski R, Jr 2004 The ErbB/HER receptor protein-tyrosine kinases and cancer. Biochemical and Biophysical Research Communications 319 1-11. 
Sanz L, Sanchez P, Lallena MJ, Diaz-Meco MT \& Moscat J 1999 The interaction of p62 with RIP links the atypical PKCs to NF-kappaB activation. EMBO Journal 18 3044-3053.

Seibenhener ML, Babu JR, Geetha T, Wong HC, Krishna NR \& Wooten MW 2004 Sequestosome 1/p62 is a polyubiquitin chain binding protein involved in ubiquitin proteasome degradation. Molecular and Cellular Biology 24 8055-8068.

Shi FD, Zhang JY, Liu D, Rearden A, Elliot M, Nachtsheim D, Daniels T, Casiano CA, Heeb MJ, Chan EK et al. 2005 Preferential humoral immune response in prostate cancer to cellular proteins p90 and p62 in a panel of tumor-associated antigens. Prostate 63 252-258.

Srinivasan R, Leverton KE, Sheldon H, Hurst HC, Sarraf C \& Gullick WJ 2001 Intracellular expression of the truncated extracellular domain of c-erbB-3/HER3. Cellular Signalling 13 321-330.

Stumptner C, Heid H, Fuchsbichler A, Hauser H, Mischinger HJ, Zatloukal K \& Denk H 1999 Analysis of intracytoplasmic hyaline bodies in a hepatocellular carcinoma. Demonstration of p62 as major constituent. American Journal of Pathology 154 1701-1710.

Stumptner C, Fuchsbichler A, Heid H, Zatloukal K \& Denk H 2002 Mallory body - a disease-associated type of sequestosome. Hepatology 35 1053-1062.
Su Y, Qian H, Zhang J, Wang S, Shi P \& Peng X 2005 The diversity expression of p62 in digestive system cancers. Clinical Immunology 116 118-123.

Thompson HG, Harris JW, Wold BJ, Lin F \& Brody JP 2003 p62 overexpression in breast tumors and regulation by prostate-derived Ets factor in breast cancer cells. Oncogene 22 2322-2333.

Torhorst J, Bucher C, Kononen J, Haas P, Zuber M, Kochli OR, Mross F, Dieterich H, Moch H, Mihatsch M et al. 2001 Tissue microarrays for rapid linking of molecular changes to clinical endpoints. American Journal of Pathology 159 2249-2256.

Wallasch C, Weiss FU, Niederfellner G, Jallal B, Issing W \& Ullrich A 1995 Heregulin-dependent regulation of HER2/neu oncogenic signaling by heterodimerization with HER3. EMBO Journal 14 4267-4275.

Wooten MW, Geetha T, Seibenhener ML, Babu JR, Diaz-Meco MT \& Moscat J 2005 The p62 scaffold regulates nerve growth factor-induced NF-kappaB activation by influencing TRAF6 polyubiquitination. Journal of Biological Chemistry 280 35625-35629.

Zhang Y, Banerjee S, Wang Z, Xu H, Zhang L, Mohammad R, Aboukameel A, Adsay NV, Che M, Abbruzzese JL et al. 2006 Antitumor activity of epidermal growth factor receptor-related protein is mediated by inactivation of ErbB receptors and nuclear factor-kappaB in pancreatic cancer. Cancer Research 66 1025-1032. 